Doktorske studije traduktologije

jborljin@yahoo.com

\title{
MOTIVACIJA STUDENATA ZA UČENJE ŠPANSKOG JEZIKA NA FILOLOŠKOM FAKULTETU UNIVERZITETA U BEOGRADU
}

\begin{abstract}
APSTRAKT: Učenje nematernjeg jezika predstavlja proces koji traje čak i onda kada dostignemo određeni nivo znanja jezika u cilju održavanja željenog nivoa jezičke i komunikativne kompetencije. Predmet istraživanja ovog rada je motivacija tokom procesa učenja stranog jezika i njeni vidovi. Polazimo od činjenice da studenti španskog jezika $i$ hispanskih književnosti Filološkog fakulteta Univerziteta u Beogradu predstavljaju grupu pojedinaca koji su veoma motivisani za učenje španskog jezika budući da su ga odabrali kao životni poziv. Cilj istraživanja je dobijanje uvida u ono što motiviše studente hispanistike da odaberu i nastave da izučavaju ovaj jezik sprovođenjem ankete koja je prethodno potkrepljena teorijskim osvrtima psihologa i primenjenih lingvista na temu motivacije.
\end{abstract}

Ključne reči: motivacija, španski kao strani jezik, životni poziv, nastavnik, nastava i učenje.

\section{MOTIVATION OF STUDENTS AT FACULTY OF PHILOLOGY, UNIVERSITY OF BELGRADE TO STUDY SPANISH LANGUAGE}

\begin{abstract}
Studying foreign or second languages is a long process which continues even when the language has been acquired in order to maintain a certain level of competence. The subject matter of the research presented in this paper is motivation during the process of learning a foreign language and its aspects. Our initial presupposition is that the students of Spanish language and Hispanic literatures at the Faculty of Philology at Belgrade University represent a group of individuals who are highly motivated to learn Spanish since they have chosen it as their future profession. The aim of the research is to gain insight into what motivates Hispanic students to choose and continue learning this language by conducting a survey previously substantiated by the theoretical reviews of psychologists and applied linguists on the topic of motivation.
\end{abstract}

Key words: motivation, Spanish as foreign language, vocation, teacher, studying and teaching.

\section{UVOD}

Motivacija predstavlja ključnu ulogu u svim aktivnostima, posebno $u$ učenju. Čini se da je motivacija jedan od ključnih faktora u učenju stranog jezika 
koje iziskuje mnogo strpljenja, utrošenog vremena, vežbanja i upornosti. Važno je prepoznati šta u datom trenutku motiviše učenika za učenje stranog jezika kako bi ta motivacija mogla da se produbi ili, pak, kako bi se sprečilo njeno opadanje ako do toga dođe. Smatramo da je istraživanje motivacije učenja španskog jezika na Filološkom fakultetu Univerziteta u Beogradu vredno pažnje jer se pojedinci koji španski jezik uče na pomenutoj instituciji bave njegovim izučavanjem gradeći svoje znanje kako bi ga koristili u profesionalne svrhe. Ono što mnogi stručnjaci nastoje da dokuče jeste šta stoji iza te motivacije i na koje načine možemo da utičemo na nju, usmeravajući je i povećavajući.

Nakon prvog odeljka koji se bavi teorijama motivacije, biće reči o motivaciji učenja i teorijama koje su usko vezane za nju, kao i o samoj motivaciji za učenje stranih jezika. Na kraju ćemo se, zahvaljujući teorijskoj potpori, baviti i analizom rezultata ankete koju smo sproveli sa studentima hispanistike Filološkog fakulteta (FF) Univerziteta u Beogradu.

S obzirom na to da učenje stranog jezika predstavlja interakciju nekoga ko zna strani jezik, u najvećem broju slučajeva nastavnika, i onoga ko taj jezik uči, jedan odeljak ovog rada bavi se ulogom nastavnika kao motivišućeg faktora $u$ procesu učenja stranog jezika.

Cilj ovog istraživanja je prepoznavanje osnovnih razloga koji studente FF motivišu da uče (i proučavaju) španski jezik. Budući da se ovi studenti opredeljuju za životni poziv koji podrazumeva nastavni proces osvrnućemo se na faktore koji utiču na takvo opredeljenje.

\section{MOTIVACIJA}

Premda psihologija predstavlja relativno mladu naučnu disciplinu, dosadašnja istraživanja ukazala su na njenu složenost (Holtzman 1984: 187). Jedna od oblasti kojima se psihologija bavi, a koja se ističe svojom kompleksnošću jeste svakako motivacija. Pomenutu kompleksnost oslikava i potvrđuje veliki broj teorija koje izučavaju i objašnjavaju motivaciju (Žiropađa, Miočinović 2007: 63). Samo poreklo reči motivacija ${ }^{l}$ upućuje na njenu suštinu: zašto nešto radimo, šta nas pokreće, koji je razlog. Osnovna definicija motiva je da su to psihološki činioci koji pokreću na aktivnost, usmeravaju i održavaju aktivnost radi dostizanja cilja kojim se može zadovoljiti određena potreba (Kordić, Pajević 2007: 108).

${ }^{1}$ Motivacija $>$ motiv > motivus (sr. lat.) > motus (lat.) - pokret (Klajn, Šipka 2006: 795). 
Motivisano ponašanje prema tumačenju Biljane Trebješanin podrazumeva „usmerenost ka cilju kojem osoba teži, zalaganje ili spremnost da se uloži trud ili napor da bi se on postigao i izvesnu upornost, istrajanje u tom naporu do postizanja cilja, bez obzira na prekide, druge izazove ili prepreke." (Trebješanin 2009: 13)

Brojni psiholozi su sproveli i nastavljaju da sprovode istraživanja u okviru ove oblasti koja su formulisala nekoliko značajnih teorija o motivaciji, odnosno o razlozima postojanja motivacije ili motivisanog ponašanja (Oxford, Shearin 1994: 14). Za naše istraživanje su od velike važnosti Maslovljeva teorija motivacije, Elderferova ERG, kao i Mek Klelandova teorija potreba, budući da „nastoje da otkriju koje su grupe potreba ili motiva koje ljudi nastoje da ostvare u organizacijama i grupama" (Janićijević 2008: 112) s obzirom na to da se upravo strani jezik najčešće uči pri nekoj organizaciji u okviru neke grupe kao što su škola, školski razred i sl. (Šuković 1986: 12, 20).

\subsection{Maslovljeva teorija motivacije}

Za Maslovljevu teoriju motivacije specifično je naglašavanje fizioloških poriva kao bitnih faktora motivacije (Šuković 1986: 138). Ljudske potrebe čine jedan hijerarhijski red (Maslov prema Šuković 1986: 137-140). Na prvom mestu nalaze se fiziološke potrebe, jer tek kada su one zadovoljene, javljaju se potrebe za nečim drugim. Sledeća u nizu je potreba za sigurnošću, koja nastupa odmah posle zadovoljenja fizioloških potreba. Sledi potreba za ljubavlju da bi zadovoljenje naredne potrebe - potrebe za poštovanjem - vodilo osećanju samopouzdanja, snage, sposobnosti i mogućnosti da se bude koristan i potreban. Potreba za samoaktualizacijom, koja se ostvaruje nakon zadovoljenja prethodnih potreba, predstavlja ostvarivanje svih potencijala individue.

\subsection{Elderferova ERG teorija}

Klejton Elderfer jedan je od autoriteta u ovoj oblasti psihologije (Janićijević 2008: 103). Prema ovoj teoriji, ljude pokreću tri vrste potreba (Alderfer 1969: 156):

- egzistencijalne potrebe - (eng. Existence) - bazične, fiziološke potrebe;

- potrebe povezivanja - (eng. Relatedness) - potrebe za ljubavlju, sigurnošću;

- potrebe razvoja - (eng. Growth) - potrebe za poštovanjem i samoaktualizacijom. 
Elderfer tvrdi da određeni faktori, kao što su kulturni ambijent ili lična istorija, mogu u značajnoj meri kod pojedinca biti favorizovani, tako da jedna potreba može da bude favorizovana na račun druge. To praktično znači da pojedinci mogu da budu motivisani nekom potrebom višeg reda koja je za njih značajna (npr. potrebe pripadnosti) i pored toga što nisu zadovoljene neke potrebe nižeg reda (npr. egzistencijalne), ukoliko su te potrebe višeg reda iz nekog razloga veoma važne za datog pojedinca (Janićijević 2008: 116).

\subsection{Mek Klelandova teorija potreba}

Dejvid Mek Kleland takođe navodi tri vrste potreba (McClelland prema Janićijević, 2008: 120):

- potrebe pripadanja - (eng. Need for affiliation);

- potrebe postignuća - (eng. Need for achievement);

- potrebe moći - (eng. Need for power).

Novina koju ova teorija donosi jesu potrebe postignuća i potrebe moći. Što se tiče potrebe postignuća Janićijević je definiše kao zadovoljstvo koje se stiče nakon uspešno odrađenog zadatka (Janićijević 2008: 125). Osobe koje imaju izraženu ovu potrebu, ispunjavaće zadatke na poslu ili fakultetu ne zbog nagrade nego zbog osećaja zadovoljstva koje određeno postignuće donosi.

\section{MOTIVACIJA ZA UČENJE}

Prema Filu (Fil 1978: 7-8) jedan od najvećih segmenata oblasti motivacije je upravo motivacija za učenje. Ono što naučnici žele da otkriju jeste šta pokreće osobu na određenu aktivnost, odnosno učenje, šta dovodi do toga da se u jednu aktivnost potpuno udubi, da bude istrajna, dok drugu obavlja površno ili od nje lako odustaje (Petković 2011: 23).

Prema Trebješanin (Trebješanin 2009: 16-25), teorijska stanovišta koja definišu različite kategorije motivacije za učenje su:

- Bihejvioristički pristup - sredinski činioci su glavni razlozi ponašanja. Potrebno je detaljno analizirati potkrepljivanja i kazne koje se primenjuju na grupu učenika kako bi se razumela motivacija učenika ili studenta za različite aktivnosti, pa i za aktivnost učenja; 
- Kognitivistički pristup - u zavisnosti od učenikovih vrednosti, ciljeva, očekivanja zavisi koliko će učenik biti motivisan određenim potkrepljenjem;

- Socijalno-kognitivistički pristup - predstavlja „shvatanje da učenje i motivacija za učenje uključuju recipročnu interakciju personalnih (kognitivnih) činilaca, ponašanja i karakteristika sredine" (Trebješanin 2009: 20);

- Sociokulturološki pristup - na osnovu koga se do učenja, pa samim tim i razvoja, dolazi u procesu interakcije osobe sa socijalnim i materijalnim proizvodima kulture, uz podršku i posredovanje drugih ljudi, pre svega onih koji su na višem razvojnom stupnju, tj. koji znaju više (Trebješanin 2009: 21). Ono što se ističe u ovoj teoriji je da učenik usvaja bitna shvatanja, ponašanja, pa i način razmišljanja učestvujući u aktivnostima kojima rukovode druge osobe. Upravo to za rezultat daje porast praktičnih znanja koja će unaprediti i samu motivaciju za učenje. Fil (Fil 1978: 81) je naznačio da „motiv ne postoji sam za sebe; njegovo značenje, pa prema tome i sklonosti ka određenom ponašanju, daje društvena sredina".

Autorka ovog rada smatra da upravo sociokulturološki pristup determiniše učenje, tj. usvajanje stranog, pa tako i španskog jezika studenata FF, jer se jezik uči i usvaja kako na časovima samog savremenog jezika uz direktan kontakt sa nastavnikom kojem je u većini slučaja španski jezik i maternji, tako i kroz časove književnosti i kulture koji se na višim godinama izučavaju na ciljnom jeziku, takođe sa nastavnicima sa španskog govornog područja.

Treba, takođe, pomenuti i postojanje unutrašnje (integrativne) i spoljašnje (instrumentalne) motivacije za učenje. Prema Trebješanin (Trebješanin 2009: 25) kod unutrašnje motivacije izraženo je učenikovo interesovanje za gradivo, njegova želja da nauči nešto više o nastavnoj jedinici, tako da je znanje temeljnije i duže traje, dok je kod spoljašnje motivacije situacija obrnuta: znanje je površnije i kraće traje, jer učenik nije zainteresovan već uči da bi zadovoljio neki spoljašnji motiv (nagrada, pohvala, ocena ili neki drugi specifičan cilj).

\section{MOTIVACIJA ZA UČENJE STRANOG JEZIKA}

Aleksandra Petković u svojoj knjizi Učenje stranih jezika i motivacija (Petković 2011: 15-32) faktore za učenje stranog jezika deli u dve grupe: unutrašnje i spoljašnje. Unutrašnji faktori su oni koji su direktno povezani sa karakteristikama učenika: uzrast, sklonost ka učenju, motivacija, kognitivni stil, 
afektivni/emotivni faktori. Među spoljašnjim faktorima autorka ubraja prijatnu atmosferu, lingvistički input, tj. jezički materijal, interakciju sa izvornim govornicima, motivaciju za učenje jezika. Ono što mnogi smatraju relevantnim za učenje drugog jezika jesu spoljašnji faktori. Bitno je naglasiti da nijedan od ovih faktora ne funkcioniše samostalno i da su od podjednake važnosti i spoljašnji i oni unutrašnji kako bi se stiglo do cilja - uspešno usvajanje jezika (de Marco 2000 prema Petković 2011: 18).

\subsection{Socio-psihološka teorija motivacije u učenju stranih jezika}

Prema tvorcu ove teorije, Gardneru (Gardner 1985: 53) motivaciju čine četiri komponente:

- cilj učenja;

- intenzitet motivisanosti, tačnije napor koji se ulaže u učenje zajedno sa određenim osobinama samog učenika;

- Želja da se jezik nauči;

- stavovi prema činu učenja i prema jeziku.

Ukoliko je učenik zaista motivisan, sve četiri komponente su aktivne. S obzirom na to da učenje stranog jezika može da utiče na izgradnju pozitivnih stavova prema jeziku, kao i prema samoj kulturi zemlje ili zemalja u kojima se govori, društveni i kulturni kontekst je veoma bitan za određivanje i jačanje motivacije. U toku svog istraživanja o motivaciji, uzimajući u obzir društveni i kulturni kontekst, Gardner je napravio razliku između integrativne (pozitivan stav prema jeziku i kulturi stranog jezika) i instrumentalne orijentacije (praktični razlozi učenja ciljnog jezika: prolazna ocena, unapređenje, veća mogućnost zaposlenja).

Može se zaključiti da, ukoliko je socio-lingvistički status jezika koji pojedinac uči, tj. usvaja viši u odnosu na njegov maternji, prvi jezik, da će se pre javiti instrumentalna motivacija, dok bi u obrnutoj situaciji bila integrativna. Gardner (Gardner 1985: 62) navodi da faktore u društveno-obrazovnom modelu motivacije možemo svrstati u četiri grupe: stavovi prema zajednici govornika ciljnog jezika, karakteristike vezane za kurs ciljnog jezika (stav učenika o kursu koji pohađa, nastavniku, stav roditelja prema jeziku i kursu), motivacioni indeksi i opšti stavovi (opšti odnos prema učenju, prema učenju stranih jezika, prema autoritetu, prema izvornoj kulturi i društvu). 


\subsection{Procesni model motivacije}

Topalov ističe da oni izvori motivacije koji se nalaze u neposrednoj blizini učenika imaju najsnažniji uticaj (Topalov 2011: 67). Vrlo lako se uočava da su upravo situacije i okolnosti koje susrećemo u učionici kao mestu učenja stranog jezika, najbliskije u neposrednom okruženju samog učenika. Treba uzeti u obzir da proces učenja, tj. usvajanja jezika jeste proces koji traje, često i godinama i da je sasvim normalno da se nivo motivacije menja u toku tog vremenskog perioda.

\section{FAKTORI KOJI UTIČU NA ODABIR ŽIVOTNOG POZIVA}

S obzirom da ispitanici istraživanja ovog rada uče, tj. usvajaju španski jezik sa ciljem da im to bude životni poziv sledeće poglavlje će se baviti faktorima koji utiču na izbor budućeg zanimanja u profesionalnom smislu.

Profesionalna aspiracija je snažna želja pojedinca da se bavi onim zanimanjem koje smatra vrednim, idealnim za sebe (Purić 2007: 35). Interesovanja igraju bitnu ulogu u odabiru zanimanja jer je to polazna tačka, za mnoge i jedina, pri procesu donošenja odluke.

Želja za određenim zanimanjem je pozitivan odnos emocionalne prirode, $\mathrm{u}$ kojem postoji samo približno poznavanje onog što se želi i uslova da se do njega dođe. Želja i mašta idu zajedno, realnost se ulepšava i posmatra jednostavno. Ako pri tom postoji i delimično poznavanje cilja, često ne postoji poznavanje metoda i sredstava da se on dostigne. Želja pored toga ne uključuje praktičnu akciju (Hershenson, Roth 1966: 369).

Mnogi istraživači su pokušali da pronađu vezu između interesovanja i sposobnosti kao činilaca pri odabiru zanimanja, a prema Purić (Purić 2007: 37) svako od njih je došao da zaključka da korelacija postoji. Ona, međutim, ne mora biti od ključnog značaja. Dalje, vrednosti se smatraju trajnim karakteristikama ličnosti koje se formiraju kroz socijalno učenje, koje je usmereno društvenim normama i imaju funkciju da ih zadovolje (Purić 2007: 40). Stoga možemo zaključiti da samo odluka o nastavku obrazovanja na visokim studijama može biti uslovljena ovim faktorom, a da interesovanje ne prednjači u smislu primarnog faktora za odabrani fakultet. Tako dolazi do situacija da pojedinci upisuju određeni fakultet pod uticajem nekih drugih faktora (roditelja, ekonomskog, pa i samog društvenog faktora), a ne zbog izraženog interesovanja.

Adekvatan izbor zanimanja nema samo povoljan ishod za pojedinca već ima veliki značaj i sa socijalno-ekonomskog stanovništa. Ukoliko pojedinac radi ono u čemu uživa, u obavljanje posla ulaže veći trud i obavlja ga savesnije. Osoba 
koja voli ono što radi uvek će se samonadograđivati kako svesno tako i nesvesno, što otvara put ka izvrsnosti u okviru posla, a sve navedeno ima veoma povoljan uticaj i na samo društvo.

Sa duge strane, potrebno je naglasiti da donošenje ovakve odluke svakako nije jednostavno. Purić navodi najkarakterističnije momente koji otežavaju opredeljenje i izbor pravog zanimanja.

- Prvi otežavajući faktor u pravom profesionalnom opredeljenju je nedovoljna informisanost $i$ ograničeno saznanje o karakteristikama zanimanja.

- Sledeći faktor je u vezi sa čestim promenama kriterijuma prema kojima društvo i pojedinci vrednuju određena zanimanja. Današnje potrošačko društvo preferira zanimanja koja omogućuju brzi dolazak do kapitala i statusa. Kao rezultat javlja se „velika disproporcija između društvenih potreba za pojedinim kadrovima i želja i interesovanja mladih" (Purić 2007: 42).

\section{NASTAVNIK KAO MOTIVIŠUĆI FAKTOR ZA UČENJE STRANOG JEZIKA}

Svi stručnjaci koji se bave pitanjem motivacije za učenje ne zanemaruju ulogu nastavnika, jer se motivacija razvija upravo u toku školskog učenja (Trebješanin 2009: 64), što se direktno može i primeniti kod motivacije učenja stranog jezika.

Podržavajući motivacioni diskurs uključuje nastavnikovo vrednovanje učenikovog napredovanja, izražavanje i podsticanje pozitivnih emocija u nastavnim situacijama i prepoznavanje $\mathrm{i}$ redukovanje negativnih emocija, podsticanje $\mathrm{i}$ unapređivanje saradnje $\mathrm{u}$ razredu, ohrabrivanje učenika koji se razlikuju od drugih po svom načinu ili tempu rada i dr. Nepodržavajući motivacioni diksurs podrazumeva usredsređenost na greške učenika, izražavanje i izazivanje neprijatnih emocija u nastavnim situacijama (strah, neprijatna napetost, strepnja) i podsticanje međusobnog poređenja učenika (Isto 2009: 80).

Vrlo je bitno da nastavnik kod učenika ne stvara frustracije čiji je efekat vrlo demotivišući. Kada govori o potkrepljivačima i kaznama, Trebješanin (Trebješanin 2009: 31, 69-73) postavlja slična pitanja - šta ako su očekivanja osobe izneverena; šta ako obećanja nisu ispunjena? Zaključuje da se dolazi do stanja frustriranosti koje usmerava ponašanje u nepoželjnom smeru. Za uspešnu motivaciju učenika preporučuje sa da nastavnik samo gradivo poveže sa interesovanjima učenika, da unosi novine, iznosi zanimljive informacije. Ono što 
takođe pozitivno utiče na motivaciju je tip nastave u kojoj se učenici angažuju u aktivnostima koje nisu rutinske (Trebješanin 2009: 69, 73).

Imajući u vidu činjenicu da školski sistem u velikoj meri oslikava bihejviorističko gledište, Trebješanin (Isto 2009: 32, 45) smatra da je od izuzetne važnosti da nastavnik vodi računa o potkrepljivanju i kažnjavanju učenika kako bi se podstakla motivacija.

\section{EMPIRIJSKO ISTRAŽIVANJE}

U ovom delu rada bavimo se analizom rezultata do kojih smo došli anketiranjem informanata. Anketa, koja predstavlja fokus našeg istraživanja, rađena je sa odabranim studentima sve četiri godine osnovnih akademskih studija španskog jezika i sa studentima upisanim na master akademske studije sa ciljem da se prati razvoj motivacije za učenje stranog jezika kroz sve stepene studija. Ukupan broj ispitanika je 42, od toga 9 studenata prve godine, 8 studenata druge, 11 studenata treće godine, 4 studenta četvrte, 9 studenata master studija i jedan doktorand čije smo rezultate koristili kao pokazatelje visoke motivacije, s obzirom na to da je u pitanju student doktorskih akademskih studija. Svi informanti su popunjavali anketu elektronski. Anketa je sastavljena na sajtu FluidSurvey.com i prosleđena na odgovarajuće stranice društvene mreže Fejsbuk kao što su Filološki fakultet Univerziteta u Beogradu i Hispanistika: Profesore, kaće rezultati...?

Pitanja iz ankete sastavljana su na osnovu teorija predstavljenih u teorijskom okviru rada. Podeljena su u tri grupe kako bi lakše pratila teorijsku osnovu. Prva grupa pitanja odnosi se na motivaciju za učenje, druga na Filološki fakultet kao mesto gde se znanje stranog jezika stiče, a treća na pitanja u vezi sa odabirom životnog poziva. U nastavku sledi analiza dobijenih odgovora.

\subsection{Pitanja koja se odnose na motivaciju za učenje}

Na pitanje Šta vas najviše motiviše 47,6\% ispitanika je odgovorilo da ih najviše motiviše pohvala, dok nije bilo ispitanika koji je odgovorio da ga najviše motiviše kritika. Međutim, predloženi su i odgovori: pohvala, nagrada ako se radi o nес̌ети и с̌етu sebe smatram vrlo dobrim/om i obrnuto, kritika/kazna ako se radi o nес̌emu и с̌етu sebe smatram osrednjim/om i kritika, kazna ako se radi o nес̌ети и с̌етu sebe smatram vrlo dobrim/om i obrnuto, pohvala, nagrada ako se radi o nес̌ети и с̌етu sebe smatram osrednjim/om gde su podeljeni odgovori (po $26,2 \%$ ). Ovaj rezultat pokazuje da je kritika ipak prisutna kao pokretač motivacije, 
ali ne toliko jasno kao pohvala i da je potrebno da nastavnik kod pojedinca uoči kad treba da je upotrebi kako bi bila delotvorna.

Na pitanje Kada spremam ispit koji se tiče izučavanja španskog jezika, spremam ga s ciljem... najviše njih, 36,6\%, je odgovorilo da dobijem što veću ocenu, dok su podjednako zastupljeni, po $29,3 \%$, odgovori: da što više naučim i da dobro naučim ono što me zanima, a ono što smatram nebitnim ne učim. Ocena mi nije bitna, jer sam svestan/na da dobro znam ono što je važno i 4,9\% je odgovorilo samo da položim.

Naredno pitanje koje se ticalo nastavka usavršavanja jezika i nakon završenih studija na fakultetu gde je 66,7\% je odgovorilo Naravno, sa ili bez novčanih sredstava - jezik se uči dok si živ. Šta god budem radio/la, nastaviću sa učenjem španskog, sigurno što je siguran dokaz visoke motivisanosti; $21,4 \%$ je odgovorilo Koliko mi obaveze budu dozvoljavale, ali ću se truditi da nastavim; 9,5\% je odabralo odgovor Kada budem završio/la fakultet, podrazumeva se da sam usavršio/la španski jezik. Trudiću se koliko budem mogao/la da održavam nivo stečen na fakultetu i samo $2,4 \%$ se nada da neće više imati dodira sa španskim jezikom.

Na pitanje Da li koristite, pored Vašeg znanja, još neke izvore informacija (puškice, dogovaranje sa kolegom/koleginicom i sl.) na ispitu nekog predmeta koji se tiče izučavanja španskog jezika? 23,8\% se izjasnilo da nikad nije koristilo ništa više osim sopstvenog znanja, 61,9\% vrlo retko, dok 11,9\% često koristi dodatne izvore informacija, a 2,4\% ih koristi vrlo često.

Njih 53,7\% se izjasnilo da aktivno učestvuje u komunikaciji na španskom jeziku na časovima, dok 39\% komunicira samo kada ga neko nešto direktno pita, a 4,9\% (2 ispitanika) nerado razgovara na španskom jer drugi pričaju bolje od njih. Oba studenta su studenti prve godine osnovnih studija, što onda daje potpuno novi smisao jer španski jezik može da se upiše bez predznanja, a među studentima prve godine ima i onih koji su završili Filološku gimnaziju gde su učili španski jezik.

Dalje, 36,6\% (15 ispitanika) često čita dodatne knjige pored obavezne lektire, dok 56,1\% (23 ispitanika) čita ponekad, a 7,3\% (3 ispitanika) ne čita ništa mimo obavezne lektire.

S obzirom da spoljni uticaji direktno utiču na motivaciju za učenje, tačnije kvalitet života, na pitanje Kako biste okarakterisali svoj studentski život, 7,3\% ispitanika nije zadovoljno, 63,4\% smatra da nije loš, dok 29,3\% smatra da ima odličan studentski život.

Kako bi se ispitalo postojanje lingvističke anksioznosti, pored pitanja o aktivnom učestvovanju u komunikaciji, trebalo je da ispitanici odgovore na pitanje da li osećaju tremu pred ispite. Nijh 26,8 \% tremu oseća često, 51,2\% samo 
ponekad, a $22 \%$ ispitanika oseća tremu retko. Odmah je usledilo pitanje o razlogu treme na koje su ispitanici odgovorili sledeće: 29,3\% nedovoljno savladano gradivo, 45,3\% je naznačilo strah od neuspeha kao odgovor, 12,2\% se plaši tuđeg razočaranja u njih same, dok 2,4\% ima strah da neće ispuniti očekivanja okoline.

Od ukupnog broja ispitanika, njih 48,8\% smatra da ima dobre radne navike, a $65,9 \%$ njih bi se svrstalo u one koji spremanju obaveze pristupaju neposredno pred ispite, dok 51,52\% misli suprotno. Onih koji redovno uče ima $31,7 \%$.

Na pitanje Kakvo je Vaše interesovanje za španski jezik u odnosu na period kada ste počeli da ga učite? - 67,4\% njih je označilo da im se interesovanje povećalo, dok je 20,9\% informanata odgovorilo da je interesovanje nepromenjeno, a 11,6\% smatra da im je interesovanje smanjeno u odnosu na početak studiranja.

Prema ispitanicima, na motivaciju za učenje španskog jezika najviše utiče sam jezik (64,3\%), zatim kultura (45,2\%). Njih 14,3\% procenjuje da je motivišuća okolnost mišljenje da se španski jezik smatra lakim za usvajanje, dok je jedna osoba izdvojila mogućnost putovanja kao razlog $(2,4 \%)$. Dvoje ispitanika je navelo hispanoameričke sapunice kao razlog učenja španskog $(5,2 \%)$. Što se tiče jezika i kulture, rezultati se poklapaju sa rezultatima ankete sprovedene koju su sproveli Espi i Asurmendi² (Espí, Azurmendi, 1996: 70), dok je situacija skroz suprotna kod putovanja. Međutim, ono što smo uvideli upoređujući njihovo istraživanje sa našim jeste da poreklo maternjeg jezika determiniše strani jezik kao težak ili lak.

Na pitanje Ako propustim neko predavanje iz nastave vezane za izučavanje španskog jezika..., 74,4\% ispitanika dalo je odgovor trudim se da nadoknadim tako što ću se raspitati kod kolege/inice ili kod samog nastavnika/ce, njih 16,3\% bi zamolilo nekog od kolega da joj/mu sažeto prepriča gradivo samo ako predavač naglasi nešto vrlo bitnim, a 9,3\% njih misli da ima pravo da izostane, te se neće raspitivati o gradivu.

\footnotetext{
${ }^{2}$ U anketi je učestvovalo 69 učenika mlađih od 25 godina koji su učili španski jezik u San Sebastijanu sa ciljem da se ispita motivacija učenja španskog jezika. Od ukupnog broja ispitanika, 64\% je poreklom iz Sjedinjenih Američkih Država, 21\% iz Švedske, a ostali su iz drugih evropskih zemalja. Nakon dobijenih rezultata, Espi i Asurmendi su utvrdili da je prvenstveni razlog učenja španskog jezika mogućnost putovanja u hispanske zemlje. Na drugom mestu su razlozi povezani sa komunikacijom na ovom jeziku i veća mogućnost poznastava. Stavovi koje učenici imaju prema španskom jeziku su uglavnom pozitivni. Smatraju da je koristan, bitan, neophodan, dostojan divljenja, dok su pridevi lak, moderan i naučni na samom dnu lestvice.
} 
Onih koji uglavnom ispune ciljeve u vezi sa učenjem ima 53,5\%, dok $34,9 \%$ njih ispunjava ciljeve do $75 \%$, a $11,6 \%$ njih misle da se precenjuju, te ne ispunjavaju ciljeve.

Od svih ispitanika, njih $71,4 \%$ se izjašnjava da voli španski jezik zbog njega samog, 16,7\% zbog kulture, a 2,4\% informanata voli španski zbog hispanske književnosti.

Na pitanje da li roditelji podržavaju ispitanike pri odabiru životnog poziva, $86 \%$ je potvrdilo, dok $14 \%$ njih ističe da nisu u početku, ali su vremenom roditelji počeli da pružaju podršku.

$\mathrm{Na}$ pitanje da li bi upisali doktorske studije na istoj katedri 39,5\% ispitanika je odgovorilo da ne bi upisali na Filološkom fakultetu u Beogradu, njih $25,6 \%$ bi upisali da nema materijalne barijere, jer im je posao bitniji od doktorskih studija; $27,9 \%$ njih je zadovoljno osnovnim/master studijama, a 2,4\% ispitanika je već na doktorskim studijama.

\subsection{Pitanja koja se odnose na Filološki fakultet Univerziteta u Beogradu}

Na pitanje Atmosferu na časovima koji se tiču izučavanja španskog jezika bih opisao/la: $38,1 \%$ ispitanika je odabralo odgovor $u$ većini slučajeva časove bih opisao/la zanimljivim; nastavnicile se trude da nam što više približe gradivo, ali neke nastavne jedinice jednostavno nisu zanimljive, pa nastavnik tu ne može mnogo da utiče po pitanju interesantnosti, dok 35,7\% misli da je često ,mlaka" atmosfera na časovima; nastavnik/ca dođe da kaže šta treba da ispredaje, slušaju ga/je oni studenti $i$ studentkinje koje zanima nastavna jedinica, dok ostali pronalaze zanimaciju u nес̌emu drugom: mobilnom telefonu, knjizi, tihom razgovoru sa kolegom/koleginicom...; 23,8\% ispitanika misli da je uglavnom atmosfera na svim časovima ista - nastavnik/ca predaje, ponekad se neko uključi od studenata $i$ studentkinja sa nekim pitanjem ili odgovorom; neki časovi su zanimljiviji od drugih isključivo u zavisnosti koliko me interesuje nastavna jedinica, a 2,4\% ispitanika smatra da je vrlo interesantno, nastavnici/e se trude da učine gradivo što lakšim za usvajanje; imamo vrlo bogatu konverzaciju sa nastavnicima/cama $i$ vrlo često dolazimo zajedno sa njima do zaključaka koji se tiču nastavne jedinice.

Što se tiče prisustva humora na časovima, $61,9 \%$ ispitanika tvrdi da ga ima vrlo retko, 23,8\% njih se opredelilo za odgovor nikad, a 11,9\% kaže da je često prisutan, dok 2,4\% smatra da je vrlo često prisutan. Ako uzmemo u obzir spoljašnji faktor atmosfere na času, koji je istaknut u odeljku 4, kao nešto što veoma utiče na motivaciju učenika, zaključujemo na osnovu ovog i prethodnog pitanja da većina studenata Filološkog fakulteta ne posmatra atmosferu na časovima kao motivišuću. 
Ispitanici koji smatraju da ih nastavnici ponekad savetuju kako da najbrže savladaju određeni deo gradiva spaduju u grupu od $47,6 \%$, dok $40,5 \%$ njih tvrdi da nastavnici uopšte to ne rade, a $11,9 \%$ njih tvrdi da ih često savetuju u vezi sa tom temom.

Na pitanje Ko ili šta je najveći podsticaj motivacije za učenje španskog jezika na Filološkom fakultetu? 65,9\% ispitanika smatra da motivacija potiče isključivo od samog studenta, dok njih 9,8\% smatra da je nastavnik taj koji treba da podstiče motivaciju, a njih $14,6 \%$ to pripisuje nastavnom gradivu. Njih $2,4 \%$ smatra da je raspored predavanja najveći podsticaj motivacije za učenje španskog jezika.

Konsultacije se predavačima 2,3\% ispitanika posećuje čim ima nedoumicu, $65,1 \%$ njih je odabralo odgovor posećujem kada sam siguran/na da informaciju ne mogu da nađem na drugom mestu i 32,6\% ih nikada ne posećuje.

Kada su u pitanju najbitnije karakteristike jednog nastavnika/ce stranog jezika, 62,8\% ispitanika misli da su to želja i umeće da drugima prenese znanje, $14 \%$ smatra da je to dobra priprema i organizovanost, $23,3 \%$ smatra da je to sposobnost podsticanja studentske motivacije, dok se niko nije opredelio za odgovore Smisao za humor i Spremnost da pomogne.

Na pitanje gde su se ispitanici izjašnjavali da li smatraju da su potrebne promene u nastavi španskog jezika na Filološkom fakultetu u Beogradu, njih $83,7 \%$ smatra da su potrebne, dok $16,3 \%$ njih smatra obrnuto. $77 \%$ od onih ispitanika koji su odgovorili potvrdno su i predložili sledeće promene:

- potpuna reformacija programa, načina predavanja $i$ organizacije, kao $i$ stav $i$ način odnošenja profesora i prema onome što predaju, kao i prema studentima;

- osveženje nastavnog kadra, zanimljivija predavanja;

- više rada sa studentima na predavanjima, motivisanje $i$ podsticanje njihovog interesovanja na istim;

- više konverzacije na časovima jezika, a na časovima književnosti veća angažovanost nastavnika (da ne čita gradivo sa predugačkih prezentacija, nego da višse sam objašnjava gradivo), promena akreditacije, da npr. predmeti Književnost 7 i 8 nose 6 kredita umesto 3 i da se hispanoamerička savremena književnost više radi;

- $\quad$ da se uvede više prevođenja, više prakse i više manifestacija ili sekcija da bi samim tim napredovali u učenju kako jezika tako i kulture i književnosti;

- da profesori ne budu snobovi i da se trude da što više naučimo;

- korišćenje drugih udžbenika; 
- za početak bolji profesori, bolja motivacija, zainteresovanost, opšta pismenost $i$ poznavanje predmeta koji se predaje, posebno metodike nastave;

- da se poradi na većoj organizovanosti nastave, kao i da profesori budu spremni za veću saradnju sa studentima;

- inovacije u nastavi.

\subsection{Pitanja koja se tiču životnog poziva}

Na pitanje zašto su upisali španski jezik, 73,7\% je odgovorilo da bi nešto više naučio/la o španskom jeziku, kulturi, književnosti, 21,1\% njih kako bi imali veću šansu da nađu posao.

U skladu sa prethodnim odgovorom, $81 \%$ ispitanika je upisalo španski jezik i hispanske književnosti jer uživa[ju] proučavajući španski jezik $i$ hispanske književnosti, a o zaposlenju nis[u] mnogo razmišlja[li] kada s[u] bira[li] koji ć[e] fakultet da upiš[u]; 7,1\% njih smatra španski jezik vrlo perspektivnim, te da će lako naći posao nakon studija, dok 9,5\% njih nije znalo šta drugo da upiše.

Kada završe studije, $35,7 \%$ ispitanika bi volelo da se zaposl[e] $u$ struci i $u$ slučaju da se to ne dogodi odmah, uz trenutni posao bi traž[ili] zaposlenje u struci gde bi radi[li] i za manju platu. Veruj[u] da bi vremenom napredova[li]; 35,7\% ispitanika je nastavilo rečenicu da se zaposlim, a ukoliko zaposlenje nije u struci, ako bi "iskrsla" prilika za tako nečim, napustio/la bih trenutni posao u slučaju da plata bude bar ista ili veća; $23,8 \%$ njih bi volelo da se zaposli tamo gde bi im plata odgovarala, a $4,8 \%$ njih bi tražilo posao van struke.

$\mathrm{Na}$ osnovu teorija motivacija učenja o kojoj je bilo reči u odeljku br. 3, možemo zaključiti na osnovu rezultata ankete da, gde 43,9\% ispitanika ima planove šta će raditi kad završe fakultet, a 56,1\% njih nema, prva grupa je više motivisana za učenje od druge.

Njih 43,9\% bi volelo da radi kao prevodilac, a 31,7\% kao predavač, dok bi $19,5 \%$ njih volelo da radi nešto drugo.

Kao dokaz velike motivacije za učenje španskog jezika svakako je odgovor da je 97,7\% ispitanika želelo da upiše Španski jezik i hispanske književnosti kao prvu želju, dok jednoj osobi to nije bila prva želja.

Ponovo bi upisalo studije španskog jezika i hispanskih književnosti 78,6\% ispitanika, a 14,3\% ne bi upisalo isti fakultet, dok bi 7,1\% upisalo Filološki fakultet u Beogradu, ali se ne bi opredelilo za studije španskog jezika.

$\mathrm{Na}$ osnovu informacija dobijenih pomoću ankete, može se zaključiti da su studenti Filološkog fakulteta vrlo motivisani za učenje ovog jezika i spremni su da 
posvete svoj radni život ovom poslu, iako ne bi bili zadovoljavajuće plaćeni. Njih motivišu sam jezik i kultura i upisali su ne samo smer Španski jezik $i$ hispanske književnosti nego i fakultet uopšte, kako bi izučavali ovaj jezik i njegovu kulturu, književnost, što nas dovodi do zaključka da su unutrašnje motivisani, iako se u nekim segmentima uočava spoljašnja motivacija (učenje zbog veće ocene). Unutrašnja motivacija dolazi do izražaja kod rezultata da se vrlo mali broj ispitanika odlučilo za ovaj životni poziv zbog šansi za zaposlenjem, što je jedan od osnovnih ciljeva studiranja uopšte.

Na osnovu odeljka 4.1, u kome je predstavljena Gardnerova podela faktora među kojima se nalaze i karakteristike vezane za kurs ciljnog jezika, koji zastupa mišljenje da je vrlo bitno za motivaciju šta učenik misli o instituciji u kojoj pohađa jezik, nastavniku, programu, možemo zaključiti da su studenti pokazali da najmanje motivacije dolazi od strane institucije Filološkog fakulteta.

\section{ZAKLJUČAK}

Cilj ovog rada bio je da istražimo koji faktori najviše, a koji najmanje motivišu studente hispanistike Filološkog fakulteta u Beogradu. Naše istraživanje ukazuje na to da je sam španski jezik sa hispanskim kulturama, preciznije interesovanje koje budi kod studenata, ono što pokreće njihovu motivaciju. Premda se većina ispitanika nada zaposlenju u struci, to im nije bio primarni razlog pri donošenju odluke o studijama hispanistike na Filološkom fakultetu. Teorijski osvrt i rezultati istraživanja mogli bi da doprinesu poboljšanju same nastave i nastavnog programa, ali i da podstaknu dalja istraživanja na ovu temu. Za svakoga ko se bavi učenjem jezika na visokom profesionalnom nivou, a i za nastavnika koji izvodi nastavu stranog jezika, od posebne je važnosti da ima uvid u ono što pokreće motivaciju učenja stranog jezika, u našem slučaju španskog, te je jedan od ciljeva ovog rada bio da pruži pregled teorija motivacije uopšte - preko motivacije učenja do motivacije učenja stranog jezika, i konačno da predstavi motivaciju učenja samog španskog jezika na Filološkom fakultetu Univerziteta u Beogradu.

\section{LITERATURA}

Alderfer, C. P. (1969). An empirical test of a new theory of human needs. Organizational Behavior and Human Performance 4: 142-175.

Fil, E. (1978). Motivacija. Prevod Ljubomir Žiropađa. Boegrad: Nolit.

Gardner, R. C. (1985). Social Psychology and Second Language Learning The Role of Attitudes and Motivation. London: Edward Arnold. 
Guzmán, M., Azurmendi, M. (1996). Motivación, actitudes y aprendizaje en el español como lengua extranjera. Revista española de lingüistica aplicada 11: 63-76.

Hershenson, D. B., Roth, R. M. (1966). A decisional process model of vocational development. Journal of Counseling Psychology 13(3): 368-370.

Holtzman, W. (1984). Psychology and Managerial Creativity, in Creative and Innovative Management: Essays in Honor of George Kozmetsky, eds. A. Charnes, W. W. Cooper, G. Kozmetsky (Cambridge, MA: Ballinger Publishing): 187-205.

Janićijević, N. (2008). Organizaciono ponašanje. Beograd: Data Status.

Клајн, И., Шипка, М. (2006). Велики речник страних речи и израза. Нови Сад: Прометеј. [Klajn, I., Šipka, M. (2006). Veliki rečnik stranih reči i izraza. Novi Sad: Prometej].

Kordić, B., Pajević, D. (2007). Opšta psihologija sa socijalnom psihologijom. Beograd: Društvo psihologa Srbije.

Miljanović, M. (2013). Istraživanje o motivaciji i školskom učenju. Pristupljeno 15. 9. 2019.

URL: <http://www.psihologijaonline.com/pedagoska-psihologija/162istrazivanje-o-motivaciji-i-skolskom-ucenju> .

Oxford, R., Shearin, J. (1994). Language learning motivation: Expanding the theoretical framework. The modern language journal 78(1): 12-28.

Petković, A. (2011). Učenje stranih jezika i motivacija. Beograd: Zadužbina Andrejević.

Purić, N. (2007). Unutrašnja i statusna motivacija za izbor zanimanja na adolescentskom uzrastu. Beograd: Univerzitet u Beogradu.

Šuković, F. (1986). Organizacija, grupe i motivacija. Beograd: Jugoslovenski zavod za produktivnost rada.

Topalov, J. (2011). Motivacija u nastavi stranog jezika. Novi Sad: Filozofski fakultet.

Trebješanin, B. (2009). Motivacija za učenje. Beograd: Učiteljski fakultet, Univerzitet u Beogradu.

Žiropađa, L., Miočinović, Lj. (2007). Razvojna psihologija. Beograd: Čigoja. 
Jelena M. Borljin

Pablo Olavide University, Seville, Spain

PhD program in traductology

\section{MOTIVATION OF STUDENTS AT FACULTY OF PHILOLOGY, UNIVERSITY OF BELGRADE TO STUDY SPANISH LANGUAGE}

\section{Summary}

Without studying motivation we cannot reach the answer of what stimulates us or not. The closer we are to that answer, the more we can control it. Considering the fact that learning is a process which is stimulated by both intrinsic and extrinsic motivation, it can be concluded that studying foreign languages is also simulated by these types of motivation. Studying foreign or second languages is a long process which continues even when the language is acquired in general terms, in order to maintain a certain level of competence. The Spanish language, as a language of rich culture which is spoken worldwide, attracts many people who wish to learn it. Students of Spanish language and Hispanic literatures at Faculty of Philology from Belgrade University represent a group of individuals who are highly motivated for the acquisition of Spanish since they have chosen it as their future profession. In order to understand what motivates university students of Spanish language to study it, a survey supported by a theoretical review of research carried out by psychologists and applied linguists was conducted. A conclusion can be drawn that the students are highly motivated by the language itself and its culture, and less motivated by the close setting in which they are learning the Spanish language.

Key words: motivation, Spanish as foreign language, vocation, teacher, studying and teaching. 


\section{DODATAK}

Motivacija studenata španskog jezika na Filološkom fakultetu u Beogradu

1. Zamolila bih Vas da naznačite na kojoj ste godini studija

○ Prvoj

$9-21,4 \%$

○ Drugoj

$8-19,0 \%$

○ Trećoj

$11-26,2 \%$

○ Četvrtoj

$4-9,5 \%$

- Master student

$9-21,4 \%$

- Student doktorskih studija

$1-2,4 \%$

2. Šta Vas više motiviše:

○ pohvala, nagrada

$20-47,6 \%$

○ kritika, kazna

$0-0 \%$

- pohvala, nagrada ako se radi o nečemu u čemu sebe smatram vrlo dobrim/om i obrnuto, kritika/kazna ako se

$11-26,2 \%$ radi o nečemu u čemu sebe smatram osrednjim/om

- kritika, kazna ako se radi o nečemu u čemu sebe smatram vrlo dobrim/om i obrnuto, pohvala, nagrada ako se radi o $11-26,2 \%$ nečemu u čemu sebe smatram osrednjim/om

3. Zbog čega ste upisali fakultet?

- Jer su moji roditelji tako želeli.

$0-0 \%$

- Kako bih imao/la veću šansu da nađem posao.

$8-21,1 \%$

○ Zbog titule.

$0-0 \%$

- Da bih odložio/la zaposlenje. Bolje da budem student/kinja, nego zaposlen/a.

$0-0 \%$

- Da bih naučio/la nešto više o španskom jeziku, kulturi, književnosti.

○ Iz nekog drugog razloga:

4. Upisao/la sam studije španskog jezika jer:

Završite rečenicu. 
- smatram da je španski jezik vrlo perspektivan i da ću se lako zaposliti kada završim studije.

$3-7,1 \%$

- uživam proučavajući španski jezik i hispanske književnosti, a o zaposlenju nisam mnogo razmišljao/la kada sam birao/la koji ću fakultet da upišem.

○ nisam znao/la šta drugo da upišem.

$4-9,5 \%$

○ iz nekog drugog razloga: $1-2,4 \%$

5. Kada završim studije, voleo/la bih:

- da se zaposlim u struci i u slučaju da se to ne dogodi odmah, uz trenutni posao bih tražio/tražila zaposlenje u struci gde bih radio/la i za manju platu. Verujem da bih $5-35,7 \%$ vremenom napredovao/la.

○ da se zaposlim, a ukoliko zaposlenje nije u struci, ako bi "iskrsla" prilika za tako nečim, napustio/la bih trenutni $15-35,7 \%$ posao u slučaju da plata bude bar ista ili veća.

- da se zaposlim tamo gde mi visina plate odgovara. Nije mi bitno da se zaposlim u struci.

$0-23,8 \%$

- tražio/la bih posao van struke. Što se mene tiče, ne moram da koristim znanje španskog jezika u profesionalne svrhe uopšte.

6. Atmosferu na časovima koji se tiču izučavanja španskog jezika bih opisao/la:

○ vrlo je interesantno, nastavnici/e se trude da učine gradivo što lakšim za usvajanje; imamo vrlo bogatu konverzaciju sa nastavnicima/cama i vrlo često dolazimo zajedno sa njima do zaključaka koji se tiču nastavne jedinice.

○ u većini slučajeva, časove bih opisao/la zanimljivim; nastavnici/e se trude da nam što više približe gradivo, ali neke nastavne jedinice jednostavno nisu zanimljive, pa $16-38,1 \%$ nastavnik tu ne može mnogo da utiče po pitanju interesantnosti. 
○ uglavnom je atmosfera na svim časovima ista nastavnik/ca predaje, ponekad se neko uključi od studenata i studentkinja sa nekim pitanjem ili odgovorom; neki časovi $10-23,8 \%$ su zanimljiviji od drugih isključivo u zavisnosti koliko me interesuje nastavna jedinica.

- često je „mlaka" atmosfera na časovima; nastavnik/ca dođe da kaže šta treba da ispredaje, slušaju ga/je oni studenti i studentkinje koje zanima nastavna jedinica, dok ostali pronalaze zanimaciju u nečemu drugom: mobilnom telefonu, knjizi, tihom razgovoru sa kolegom/koleginicom...

7. Kada spremam ispit koji se tiče izučavanja španskog jezika, spremam ga s ciljem...

○ da dobijem što veću ocenu. $\quad 15-36,6 \%$

○ da što više naučim. $\quad 12-29,3 \%$

- da dobro naučim ono što me zanima, a ono što smatram nebitnim ne učim. Ocena mi nije bitna jer sam svetan/na da dobro znam ono što je važno.

○ samo da položim.

8. Molim Vas okarakterišite sledeću rečenicu izjavama u nastavku:

- Naravno, sa ili bez novčanih sredstava - jezik se uči dok kod si živ. Šta god budem radio/la, nastaviću sa učenjem španskog, sigurno.

○ Koliko mi obaveze budu dozvoljavale, ali ću se truditi da nastavim.

- Kada budem završio/la fakultet, podrazumeva se da sam usavršio/la španski jezik. Trudiću se koliko budem mogao/la da održavam nivo stečen na fakultetu.

- Nadam se da neću morati više da ga izučavam.

9. Da li koristite, pored Vašeg znanja, još neke izvore informacija (puškice, dogovaranje sa kolegom/koleginicom i sl.) na ispitu nekog predmeta koji se tiče izučavanja španskog jezika?

○ Nikad.

○ Vrlo retko. $26-61,9 \%$ 
○ Često.

○ Vrlo često.

10. Da li je na časovima koji se tiču izučavanja španskog jezika prisutan humor?

- Vrlo često.

○ Često.

○ Ponekad.

○ Uopšte.

11. Da li Vas nastavnici savetuju kako da najbrže savladate određeni deo gradiva?

- Često.

○ Ponekad.

○ Uopšte.

12. Molim Vas okarakterišite sledeću rečenicu izjavama u nastavku:

Učestvujem u komunikaciji na španskom jeziku sa nastavnikom/com ili drugim studentima/studentkinjama na časovima.

- Trudim se da razgovaram na španskom što češće, pa i na časovima.

- Samo kada pitanje bude direktno meni postavljeno. Nikad prvi/a ne započinjem komunikaciju.

○ Nerado pričam na španskom, jer drugi pričaju bolje od mene.

○ Nešto drugo:

13. Da li čitate pored obaveznih lektira?

○ Često.

○ Ponekad.

- Uopšte.

14. Kako biste okarakterisali svoj studentski život:

- Nisam zadovoljan/na. Očekivao/la sam mnogo više pre upisivanja fakulteta.

○ Osrednji. Nije loš, ali može bolje.
$5-11,9 \%$

$1-2,4 \%$

$13-31,0 \%$

$20-47,6 \%$

$1-2,4 \%$

$5-11,9 \%$

$20-47,6 \%$

$17-40,5 \%$

$22-53,7 \%$

$16-39,0 \%$

$2-4,9 \%$

$1-2,4 \%$

$15-36,6 \%$

$23-56,1 \%$

$3-7,3 \%$

$3-7,3 \%$

$26-63,4 \%$ 
- Odličan. Ništa ne bih menjao/la, osim novca. Studenti nikad nemaju para na pretek.

$12-29,3 \%$

15. Da li imate tremu pred ispite?

- Često.

$11-26,8 \%$

○ Ponekad.

$21-51,2 \%$

○ Uopšte.

$9-22,0 \%$

16. Koji je razlog treme?

- Nedovoljno savladano gradivo.

$12-29,3 \%$

- Strah od neuspeha.

$19-46,3 \%$

- Bojite se da ćete razočarati prisutne, bilo to da je ispitivač, kolege/koleginice.

$5-12,2 \%$

- Nećete ispuniti očekivanja Vaše okoline.

$1-2,4 \%$

○ Nešto drugo:

$4-9,8 \%$

17. Da li smatrate da ste osoba koja ima dobre radne navike?

○ Da.

$20-48,8 \%$

○ Ne.

$21-51,2 \%$

18. Što se tiče učenja, svrstao/la bih se u grupu:

- Kampanjaca

$27-65,9 \%$

- Manipulatora (puškice i sl.)

$1-2,4 \%$

- Onih koji redovno uče.

$13-31,7 \%$

19. Da li imate planove šta ćete raditi kada završite fakultet?

○ Da.

$18-43,9 \%$

○ Ne još uvek.

$23-56,1 \%$

20. Najviše bih voleo/la da radim kao:

- Prevodilac

$20-48,8 \%$

- Predavač

$13-31,7 \%$

- Nešto drugo

$8-19,5 \%$

21. Kakvo je Vaše interesovanje za španski jezik u odnosu na period kada ste počeli da ga učite?

- Povećano.

$29-67,4 \%$

○ Nepromenjeno.

$9-20,9 \%$

- Smanjeno.

$5-11,6 \%$

22. Šta, prema Vašem mišljenju, najviše utiče na motivaciju za učenje španskog jezika? 
○ Kultura.

$19-45,2 \%$

○ Sam jezik.

$27-64,3 \%$

○ „Bije ga glas" da je lak, pa se mnogi opredeljuju za njega iz tih razloga.

$6-14,3 \%$

- Nešto drugo:

$4-9,5 \%$

23. Kada sam upisao/la fakultet, ovaj smer mi je bio prva želja

○ Da.

$42-97,7 \%$

○ Ne.

$1-2,3 \%$

24. Da mogu opet da biram koji bih fakultet upisao/la...

Završite rečenicu:

○ upisao/la bih opet španski jezik i hispanske književnosti

$33-78,6 \%$

○ sigurno ne bih opet upisao/la isti.

$6-14,3 \%$

○ upisao/la bih opet Filološki fakulet, ali ne bih odabrao/la španski jezik. Odabrao/la bih

$3-7,1 \%$

25. Ako propustim neko predavanje iz nastave vezane za izučavanje španskog jezika...

Završite rečenicu

- trudim se da nadoknadim tako što ću se raspitati kod kolege/koleginice ili kod samog nastavnika/ce.

- zamoliću nekog od kolege/koleginice da mi sažeto prepriča gradivo, ukoliko predavač naglasi da je nešto bitno.

$7-16,3 \%$

○ neću se raspitivati. Imam pravo da izostanem.

$4-9,3 \%$

26. Kada postavim sebi ciljeve u vezi sa učenjem...

Završite rečenicu

- vrlo mi je teško da ih pratim. Obično se precenim.

$5-11,6 \%$

○ ispunim ih do $75 \%$.

$15-34,9 \%$

$\circ$ uglavnom ih ispunim.

$23-53,5 \%$

27. Ko ili šta je najveći podsticaj motivacije za učenje španskog jezika na Filološkom fakultetu?

- Nastavnik.

$4-9,8 \%$

- Nastavno gradivo.

$6-14,6 \%$

- Sam student.

$27-65,9 \%$

- Raspored predavanja.

$1-2,4 \%$

○ Nešto drugo;

$3-7,3 \%$

28. Španski jezik mi se najviše dopada...

Završite rečenicu 
○ zbog njega samog. Sviđa mi se kako zvuči i način na koji mogu da se izražavam.

$30-71,4 \%$

○ zbog hispanskih književnosti. Uživam u njenim delima

$1-2,4 \%$

○ zbog hispanske kulture.

$7-16,7 \%$

○ iz drugih razloga:

$4-9,5 \%$

29. Da li Vas roditelji podržavaju pri izboru životnog poziva.

○ Da.

$37-86,0 \%$

○ Ne.

$0-0 \%$

- U početku nisu, ali su vremenom počeli da me podržavaju.

$6-14,0 \%$

- U početku jesu, ali vremenom je podrška postala sve slabija i slabija.

$0-0 \%$

30. Upisao/la bih doktorske studije na istoj katedri:

- Da nema materijalne barijere, svakako. Posao mi je što pre potreban.

$11-25,6 \%$

- Ne, zadovoljna sam osnovnim /master studijama.

$12-27,9 \%$

○ Već sam na doktorskim studijama.

$1-2,3 \%$

- Da mi je veći prosek, svakako.

$2-4,7 \%$

- Ne bih na Filološkom fakultetu u Beogradu.

$17-39,5 \%$

31. Šta biste okarakterisali kao najteži segment studiranja španskog jezika i hispanskih književnosti?

○ Jezik

$3-7,0 \%$

○ Književnost

$30-69,8 \%$

○ Kultura

$3-7,0 \%$

- Sve je u istom rangu lako.

$2-4,7 \%$

- Sve je u istom rangu teško.

$5-11,6 \%$

32. Konsultacije sa predavačima...

Završite rečenicu

○ posećujem čim imam neku nedoumicu.

$1-2,3 \%$

- posećujem kada sam siguran/na da informaciju ne mogu da nađem na drugom mestu.

$28-65,1 \%$

○ ne posećujem nikad.

$14-32,6 \%$

33. Koje su najbitnije karakteristike nastavnika/ca stranog jezika?

- Želja i umeće da drugima prenese znanje.

$27-62,8 \%$

- Dobra priprema nastave i organizovanost.

$6-14,0 \%$ 
- Sposobnosti podsticanja studentske motivacije.

$10-23,3 \%$

- Smisao za humor.

$0-0 \%$

- Spremnost da pomogne.

$0-0 \%$

34. Da li smatrate da su potrebne promene u nastavi španskog jezika na Filološkom fakultetu?

○ Da.

$36-83,7 \%$

○ Ne.

$7-16,3 \%$

Ukoliko je odgovor potvrdan, molim, predložite:

Hvala Vam na utrošenom vremenu i trudu!

Primljeno: 3. 12. 2019.

Prihvaćeno: 12. 12. 2019. 